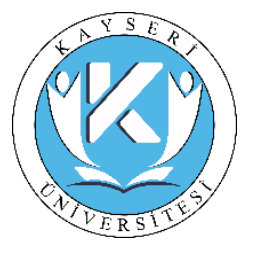

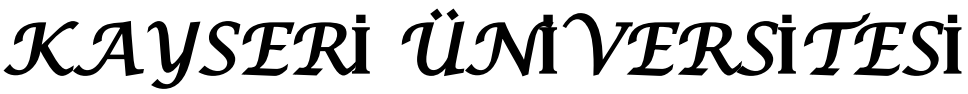 Sosyal Bilimler Dergísi

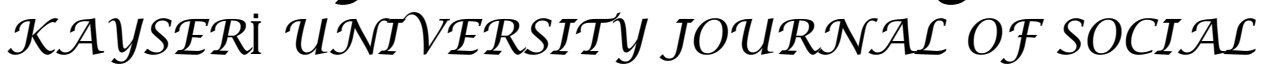 SCIE $\mathcal{N C E S}$
}

\begin{tabular}{|l|l|l|l|l|l|}
\hline Makale Türü & Araştırma makalesi & Y1l & $\mathbf{2 0 2 1}$ & ss. & 41-59 \\
\hline Gönderi Tarihi & $\mathbf{0 4 . 0 5 . 2 0 2 1}$ & Cilt & $\mathbf{3}$ & DOI & $\mathbf{1 0 . 5 1 1 7 7 / k a y u s o s d e r . 9 3 2 2 4 9}$ \\
\hline Kabul Tarihi & $\mathbf{2 3 . 0 6 . 2 0 2 1}$ & Say1 & $\mathbf{1}$ & & \\
\hline Online Yayın Tarihi & $\mathbf{3 0 . 0 6 . 2 0 2 1}$ & Ay & Haziran & & \\
\hline
\end{tabular}

\section{TR72 bölgesinde il düzeyinde inşaat-sanayi ve hizmetler sektörü yığılmasının lokasyon katsayısı yöntemiyle araştırılması* ${ }^{* \Delta}$}

\section{Investigation of the construction-industry and service sectors agglomeration at provincial level in TR72 region by location quotient method}

$\ddot{O} \mathbf{z}$

Yığılma, firmaların ve benzer sektörlerin belli bir coğrafyada bir araya gelerek yoğunlaşmasıdır. Sektörel yığılma ulaşılabilirlik, maliyetten tasarruf, yerel firmalar için yarışma avantajları sunmaktadır. Sektörel yı̆̆glma aynı zamanda kent ekonomisi için önemli avantaj sağlamaktadır. Çalışmada TR72 Bölgesini oluşturan Kayseri, Sivas ve Yozgat illerinde inşaat, sanayi ve hizmetler sektörlerinde yığglma düzeylerinin ve hangi ilde hangi sektörün baskın olduğunun araştırılması amaçlanmıştır. Çalışmada Sosyal Güvenlik Kurumu'nun il bazında yıllık sigortalı çalışan sayıları esas alınmıştır. Çalışmada yığılma düzeyinin tespitinde lokasyon katsayısı (LQ) yöntemi kullanılmıştır. Sonuçta Kayseri'de yarışabilecek seviyede sanayi sektörü yığılması; Sivas ve Yozgat illerinde inşaat ve hizmetler sektörü yığılmasının bulunduğu belirlenmiştir. İleride yapılacak olan planların sektörel tahmin ve projeksiyonlarında Kayseri'de sanayi kararlarında yığılmış işgücü varlığı, Sivas’ta inşaat sektörü yığglma düzeyinde azalma eğilimine, Yozgat'ta inşaat ve hizmetler sektörü yığılmasında artış olması hususlarına dikkat edilmesi gerektiği sonucuna ulaşılmıştır.

Anahtar Kelimeler: Kent Ekonomisi, Sektörel Yı̆̆ılma, İnşaat-Sanayi-Hizmet Sektörleri, TR72

\begin{abstract}
Agglomeration is concentration of companies and similar sectors in certain geography. Agglomeration offers accessibility, cost savings, competition advantages for local companies. Agglomeration also provides an important advantage for the urban economy. In this study, it is aimed to investigate the agglomeration levels in the construction, industry and services sectors in Kayseri, Sivas and Yozgat provinces that they constitute the TR72 Region, and which sector is dominant in which province. In the research, the annual number of insured employees of the Social Security Institution on a provincial basis had been utilized. In this work, the location quotient (LQ) method was used to determine the level of agglomeration. As a result, it has been determined that there is a construction and services sectoral agglomeration in Sivas and Yozgat provinces. In the sectoral estimates and projections of future plans, it was concluded that industrial decisions should be taken into consideration in the existence of specialized workforce in Kayseri, the level of construction sector agglomeration in Sivas, and increasing tendency in the construction and services sector agglomeration in Yozgat.
\end{abstract}

Keywords: Urban Economy, Agglomeration, Construction-Industrial- Service Sectors, TR72

\footnotetext{
${ }^{\Delta}$ Yazarlar bu çalışmanın tüm süreçlerinin araştırma ve yayın etiğine uygun olduğunu, etik kurallara ve bilimsel atıf gösterme ilkelerine uyduğunu beyan etmiştir. Aksi bir durumda Kayseri Üniversitesi KAYÜSOSDER Dergisi sorumlu değildir.

*Bu makale, Mehmet Bilgehan BAŞ'ın Erciyes Üniversitesi Fen Bilimleri Enstitüsü Şehir ve Bölge Planlama Anabilim Dalı Yüksek Lisans Tez çalışmasından üretilmiştir. Etik kurul izni gerektirmeyen çalışmalardandır.

${ }^{1}$ Erciyes Üniversitesi, Fen Bilimleri Enstitüsü, Şehir ve Bölge Planlama Anabilim Dalı Yüksek Lisans Öğrencisi, basmehmetbilgehan@gmail.com

${ }^{2}$ Prof. Dr., Erciyes Üniversitesi, Mimarlık Fakültesi, Şehir ve Bölge Planlama Bölümü, ergenbaris@gmail.com
} 
Baş, M.B. \& Ergen, B., (2021). TR72 bölgesinde il düzeyinde inşaat-sanayi ve hizmetler sektörü yı̆̆ımasinın lokasyon katsayısı yöntemiyle araştırılması.

\section{Giriș}

Firmaların coğrafi olarak yakın konumda yer seçerek yığılmalarının nedenini Alfred Marshall yaklaşık yüz yıl önce cevaplamış ve bunun nedenini vasıflı yerel iş gücü havuzu, tedarikçi bağlantısı, bilginin yayılmasından oluşan yığılma ekonomisi üçlemesi ile açıklamıştır (Potter \& Watts, 2014, s. 604). Yığılma talep yönünde daha ucuz ürüne ulaşılabilirlik, maliyetten tasarruf, gelirin artması, yerel firmalara yarışma avantajlarını sağlamaktadır (Bottazzi \& Gragnolati, 2015, s. 114). Pazar ekonomisi bölgesel-kentsel sistemde önemli bir rol oynamaktadır ve bölgesel-kentsel sitemde aşağıdaki başlıklar öne çıkmaktadır (Parr, 2014, s. 1927).

1) Bölgesel ekonomi, ekonomik organizasyonun belirli bir ölçeğini temsil eder. Bu noktada bölgesel ekonomi, sosyal ve ekonomik değişimden etkilenen farklı karmaşı bir mekânsal yapıya sahiptir.

2) Bölgesel mekânsal yapının anlaşılmasında kentsel sistem uygun bir perspektif sunmaktadır. Bölge mekânsal yapısında lokasyon teorisi kentsel sistemlerle ilişkinin tanımlanmasında önemlidir.

3) Mekânsal yapı bakış açısı ile kentsel sistem, kent-bölge örneğinde ülke ekonomik mekânın bir parçası olarak önemli rol oynamaktadır (Parr, 2014, s. 1927).

Benzer sektörlerin yığılması diğer sektörler ile yerel ekonomileri dolayısıyla kentsel ekonomiyi etkilemektedir; kentin hatta ülkenin yarışmacı yapısını desteklemektedir (Pan vd., 2020, s. 851). Kentsel sistemin lokasyon teorisi bağlamında analiz edilmesi kent-bölge ilişkisinin anlaşılmasını sağlayacağı gibi Porter'ın 1998 yılında yaptığı çalışmada vurguladığı, birbiriyle ilişikli firmaların bir coğrafyada yoğunlaşması (Demirdöğen, 2018, s. 87) durumunun anlaşılmasında önemli rol oynamaktadır. Her ne kadar firmaların belli bir coğrafyada kümelenmesi ya da sektörel yığılma, sanayi sektörü ile açıklanmaya çalışılsa da; aynı zamanda finans ve ticaret sektörleri de kümelenme ekonomilerinin avantajlarından yararlanmakta ve kümelenme özelliği göstermektedir (Pan vd., 2020, s. 851). Ekonomistler kümelenme ve sektörel yığılmayı sıklıkla eş anlamlı olarak kullanmakla birlikte, uzmanlar sektörel yığılma ve kümelenmeyi birbirinden ayırmakta ve kümelenmeyi benzer üretim yapan firmalar arasındaki sinerji ve karşılıklı işbirlikleri ile açıklamaktadır (Dîrzu, 2012, ss. 318-319). Sektörel yı ğılma zamanla firmaların arasındaki iş birlikleri ve sinerjiler oluşturarak sektörel kümelenmeyi beraberinde getirmektedir. Firmaların kümelenmesi ve birbirleri ile etkileşimi, teknolojinin yayılması, yeniliklerin aktarılması, bilgi ve becerinin o coğrafyada yayılmasıyla kümelenmenin bölge ekonomisine olumlu etkileri olduğu görülmektedir (Akgüngör, 2006, s. 169). Nayyar (2011, s. 4701) ekonomik gelişim sürecinin yapısal değişimle ilişkili olduğunu belirtmektedir. Kümelenme, teknolojinin yayılması, yeniliklerin artırılması ve bilgi ve becerinin yayılmasına olan olumlu etkileri ile kentsel ve bölgesel ekonomik gelişime önemli katkıda bulunmaktadır.

\section{Amaç ve problemin tanımlaması}

Çalışmada 2010-2019 yılları arasında TR72 Bölgesinde sektörel yığılmanın araştırılması amaçlanmaktadır. Sektörel yığılmanın devamlılı̆̆ uzmanlaşma düzeyini göstermektedir. Çalışmada problem konusu "TR72 Bölgesini oluşturan illerden hangisinde inşaat, sanayi ve hizmetler sektöründe yığılma görülmekte ve yıllar içinde değişimi nasıl gerçekleşmektedir?" sorusuna yanıt aranmaktadır.

\subsection{Materyal}

Çalışmada Sosyal Güvenlik Kurumu Başkanlığı'nın 2010, 2015 ve 2019 yılı "Sigortalı Sayılarının Kayseri, Sivas ve Yozgat illerinde ve Sektörlere (NACE rev. 2) Göre Dağılımı" verileri kullanılmıştır. Çalışmanın üç dönemde ele alınmasının temel sebebi yıllar itibariyle değişimin karşılaştırılarak değerlendirme yapılabilmesidir. 
Kayseri Üniversitesi Sosyal Bilimler Dergisí Cilt 3, Sayi: 1, Haziran 2021, 41-59

Kayseri University Journal of Social Sciences. Vol 3, NNo: 1, June 2021, 41-59

\subsection{Kapsam}

Meyer (1963) homojen bölgeler, nodal bölgeler, politik bölge olmak üzere üç ekonomik bölge tanımı yapmıştır (Parr, 2014, s. 1928). NUTS Bölgeleri Avrupa Birliği Bölgesel İstatistik Sistemine uygun veri tabanı oluşturmak, istatistiki veri toplanmak, sosyo-ekonomik analizler yapılabilmek ve bu bilgileri 1şığında bölgesel politikalar üretilmesi amacıyla; 12 Düzey-1, 26 Düzey-2 ve 81 Düzey-3 (il düzeyi) bölgesinden oluşacak şekilde 22 Eylül 2002 tarihinde Resmi Gazetede yayınlanarak oluşturulmuştur. (Taştekin, 2018, s. 79; DPT, 2002). Çalışma kapsamında NUTS-2 ve NUTS-3 bölge sınırları esas alındığından politik bölge yaklaşımı esas alınmıştır.

Çalışmada Sosyal Güvenlik Kurumunun istatistik yıllıkları ve il bazında sigortalı sayıları verisi kullanılmıştır. Çalışma kapsamında TR72 Bölgesini oluşturan Kayseri, Yozgat ve Sivas illerinde çalışan sigortalı sayılarında inşaat, sanayi ve hizmetler sektörü ele alınmıştır. Çalışmada sanayi, hizmet ve inşaat sektörleri incelenmiştir. Sanayi sektöründe NACE 10 ile NACE 32 kodları arasındaki veriler esas alınmıştır. İnşaat sektöründe NACE 41-42-43 verileri esas alınmıştır. Hizmetler sektöründe NACE 53 ile NACE 96 arasındaki veriler esas alınmıştır. Çalışmada kullanılan veriler 2010-2015 ve 2019 yıllarına aittir ve lokasyon katsayısında son on yıllık değişim araştırılmıştır.

\section{Yöntem: Lokasyon katsayısı}

Bölgesel mekânsal yapının ve sektörel yığılmanın belirlenmesi açısından lokasyon katsayısı önemli yaklaşımlardan biridir. Lokasyon katsayısı sektörel yığılmayı ölçmek için kullanılan önemli bir göstergedir ve hesaplamada kolaylık sağlaması, analiz maliyetinin az olması ve sektörel yapının mekânsal ilişkisinin kurulmasını sağlaması açısından çok yaygın olarak kullanılmaktadır (Crawley vd., 2013, s. 1854; Çiftçi, 2018, s. 553-554; Isserman, 1977, s. 33; Leigh, 1970, s. 202; Tian, 2013, s. 186). Lokasyon katsayısı coğrafi bir gösterge ve mekânsal analiz olması (Cromley \& Hanink 2012, s. 1; Gibson vd., 1991, s. 65); yerel niteliklerin karş1laştırılmas1 (Moineddin vd., 2003, s. 249), kümelenme ve ekonomik sektörel yığılmanın belirlenmesi (Tian, 2013, s. 187; Crawley vd., 2013, s. 1855; Henderson 2003, s. 2; Porter 2000, s. 16; Glaeser vd., 1992, s. 14) gibi birçok konuda kullanılan önemli bir analiz yöntemidir.

Çalışmada Sosyal Güvenlik Kurumunun istatistik yıllıkları ve il bazında sigortalı sayıları verisi kullanılmıştır. Bu verilerde incelenen sektörünün TR72 Bölgesini oluşturan bir ilin çalışan sayısı (si) incelenen sektörün TR72 Bölgesindeki çalışan sayısının oranlanmasının $(\mathrm{Si})$ bir ilin toplam iş gücü sayısının (s) TR72 Bölgesinde toplam işgücüne oranının (S) ile hesaplanması yöntemi kullanılmıştır. Her sektör ve her il için ayrı ayrı hesaplamalar yapılarak sonuca ulaşılmıştır. Çalışmada kullanılan yöntemi şu şekilde formülize etmek mümkündür:

$$
L Q_{i}=\frac{s_{i} / S_{i}}{s / S}
$$

Eğer yukarıdaki oran sonucunda $L Q_{i}<1$ çıkarsa bu seçilen ilde belirlenen sektörde yığılma olmadığ sonucu ortaya çıkar. Eğer yukarıdaki oran sonucunda $L Q_{i}=1$ çıkarsa bu ilde belirlenen sektörde rekabet edebilir olduğu sonucu ortaya çıkar. Eğer yukarıdaki oran sonucunda $L Q_{i}>1$ çıkarsa bu ilde belirlenen sektör çalışan sayısı açısından bir yığılma olduğu sonucu ortaya çıkar (Munandar vd., 2017, s. 1191; Cromley \& Hanink 2012, s. 2; Karakayac1, 2010, s. 152; Seçkin, 2015, s. 72; Şahin \& Türkoğlu, 2017, s. 430). 
Baş, M.B. \& Ergen, B., (2021). TR72 bölgesinde il düzeyinde inşaat-sanayi ve hizmetler sektörü yı̆ılmasinın lokasyon katsayısı yöntemiyle araştırılması.

\section{Bulgular}

TR72 Bölgesinin y1llar itibariyle toplam istihdam verileri incelendiğinde 2010 y1lından 2015 yılına kadar artış olduğu ve 248.834 kişiden 342.574 kişiye yükseldiği görülmektedir. Fakat toplam istihdamın 342.574 kişiden 333.065 kişiye düştüğü ve 2015 yılından 2019 yılına kadar \% -2,77 azaldığ1 görülmektedir.

\section{Tablo 1}

TR72 Bölgesi Sigortalı Çalışan Sayıları

\begin{tabular}{cccc}
\hline Sektörler & $\mathbf{2 0 1 0}$ & $\mathbf{2 0 1 5}$ & $\mathbf{2 0 1 9}$ \\
\hline İnşaat & 45.914 & 59.621 & 32.612 \\
Sanayi & 73.120 & 93.937 & 93.738 \\
Hizmetler & 62.273 & 102.978 & 120.630 \\
\hline Toplam İstihdam & 248.834 & 342.574 & 333.065 \\
\hline
\end{tabular}

Kaynak: SGK yıllık iş faaliyet gruplarına göre zorunlu sigortalı çalışan sayısı verileri

Tablo-1 sektörel olarak incelendiğinde inşaat sektörünün 2010 yılında 45.914 kişiden 2015 yılında 59.621 kişiye yükseldiği, fakat 2019 y1lında 32.612 kişiye düştüğü görülmektedir. TR72 Bölgesinde inşaat sektörünün 2010 yılında toplam istidam içinden aldığ 1 pay $\% 18,45,2015$ yılında $\% 17,4$ ve 2019 yılında \%9,79 olduğu görülmektedir. İnşaat sektörünün 2010-2019 yılları arasında sigortalı çalışan sayısı açısından düşüş eğiliminde olduğu görülmektedir.

Sanayi sektörü açısından Tablo-1 incelendiğinde 2010 yılında 73.120 kişiden 2015 y1lında 93.937 kişiye arttığı, fakat 2019 yılında 93.738 kişiye düştüğü görülmektedir. TR72 Bölgesinde sanayi sektörünün 2010 yılında toplam istihdam içinden aldığ pay \%29,38, 2015 yılında \%27,42 ve 2019 yılında ise \%28,14 olduğu görülmektedir. 2010-2015 yılları arasında sanayi sektörünün sigortalı çalışan sayısı açısından artış eğiliminde olduğu görülmektedir, fakat 2015-2019 yılları arasında yaklaşık 200 kişilik bir azalma olduğu görülmektedir.

Hizmetler sektörü açısından Tablo-1 incelendiğinde hizmetler sektöründe sigortalı çalışan sayısından 2010 yılında 62.273 kişiden 2015 yılında 102.978 kişiye yükseldiği ve 2019 yılında 120.630 kişi olduğu görülmektedir. TR72 Bölgesinde hizmetler sektörünün 2010 yılında toplam istihdam içinden aldığ pay \%25,02, 2015 yılında \%30,06 ve 2019 yılında \%36,21 olduğu görülmektedir. Hizmetler sektörünün 2010-2019 yılları arasında toplam istihdamdan aldığı payın giderek yükseldiği görülmektedir.

\section{İnşaat sektöründe yığılma (2010-2015-2019):}

Tablo 2 TR72 Bölgesinde inşaat sektörü ve toplam istihdam ile il bazında inşaat sektörü ve illerde toplam istihdam verilerini göstermektedir. Tablo 2 verilerine göre, 2010 yılında TR72 Bölgesinde sigortalı çalışan sayısı 248.834 kişidir. 2010 y1lı inşaat sektörü sigortalı çalışan sayıları verisi incelendiğinde Kayseri'de 24.625, Sivas'ta 13.102 ve Yozgat'ta 8.187 kişi çalıştığ 1 görülmektedir. İl toplam istihdamından inşaat sektörünün aldığı pay incelendiğinde Kayseri'de $\% 15,29$, Sivas'ta $\% 23,54$, Yozgat'ta \%25,44 olduğu görülmektedir. 2010 y1lında üç ilde inşaat sektöründe sigortalı çalışanların TR72 Bölgesinde toplam istihdamdan aldığı pay incelendiğinde $\% 18,45$ olduğu görülmektedir. 
Kayseri Üniversitesi Sosyal Bilimler Dergisí Cilt 3, Sayi: 1, Haziran 2021, 41-59

Kayseri University Journal of Social Sciences. Vol 3, NNo: 1, June 2021, 41-59

Tablo 2

TR72 Bölgesindeki İnşaat Sektörünün Sigortalı Çalışan Sayıları (2010)

\begin{tabular}{ccccc}
\hline Iller & $\begin{array}{c}\text { İnsaat Sektörü } \\
\text { İstihdamı (II) }\end{array}$ & $\begin{array}{c}\text { İnşaat Sektörü } \\
\text { İstihdamı (Tr72) }\end{array}$ & $\begin{array}{c}\text { Toplam } \\
\text { İstihdam (il) }\end{array}$ & $\begin{array}{c}\text { Toplam İstihdam } \\
\text { (Tr72) }\end{array}$ \\
\hline Kayseri & 24.625 & & 161.004 & \\
Sivas & 13.102 & & 55.649 & \\
Yozgat & 8.187 & & 32.181 & \\
\hline Tr72 Bölgesi & & 45.914 & & 248.834 \\
\hline
\end{tabular}

Kaynak: SGK yıllık iş faaliyet gruplarına göre zorunlu sigortalı çalışan sayısı verileri

Tablo 2 verilerine göre hazırlanan şekil 1'de TR72 Bölgesi illerinde inşaat sektöründe yoğunlaşma düzeyi görülmektedir. Şekil 1'e göre inşaat sektöründe lokasyon katsayısının Yozgat ilinde 1,38, Sivas ilinde 1,28 ve Kayseri ilinde 0,83 olduğu görülmektedir. 2010 yllında TR72 Bölgesinde Yozgat ve Sivas illerinde inşaat sektöründe yığılma olduğu görülmektedir.

\section{Şekil 1}

TR72 Bölgesi İnşaat Sektöründe Yı̆̆ılma (2010)

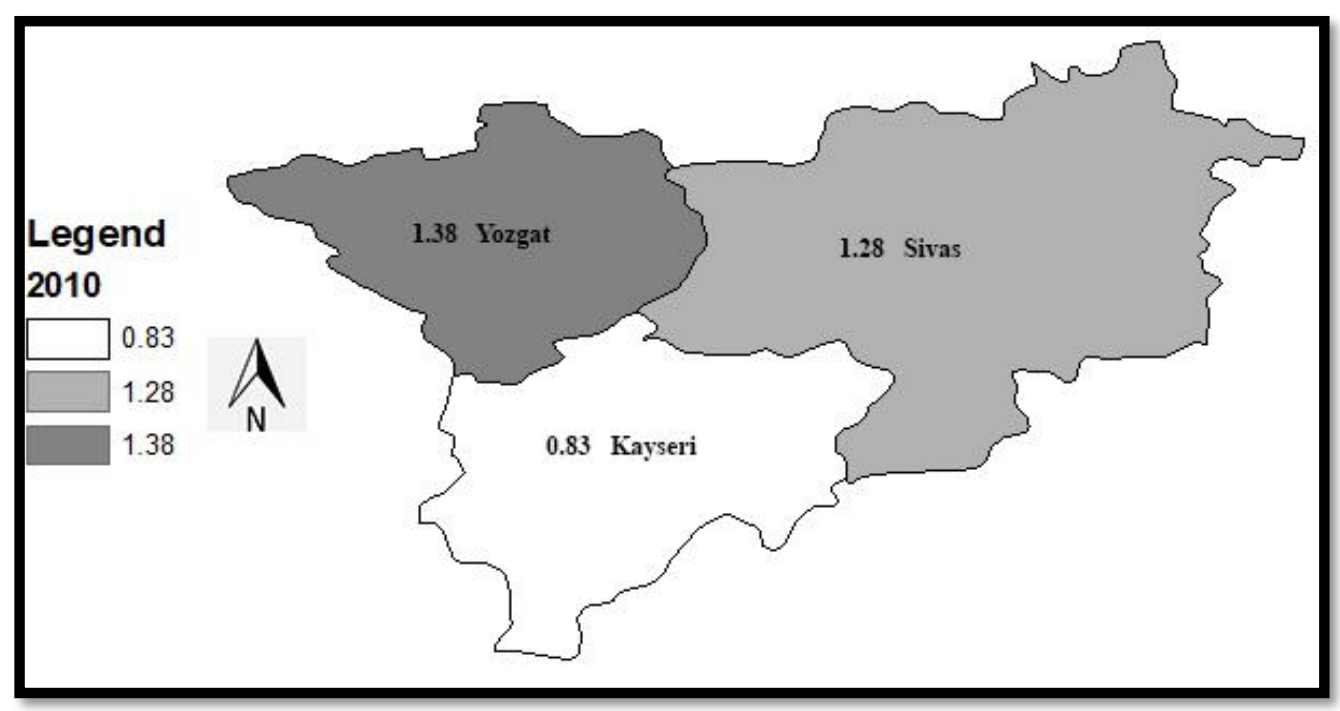

Kaynak: Bu çalışmadan esas alınarak yazar tarafindan oluşturulmuştur.

Tablo 3 incelendiğinde, 2015 y1lında TR72 Bölgesinde sigortalı toplam istihdam 342.574 kişi olduğu ve 2010 yılına göre 93.740 kişi artış gösterdiği görülmektedir. 2015 y1lında ise yılı inşaat sektörü sigortalı çalı̧̧an sayıları verisi incelendiğinde Kayseri'de 32.130, Sivas'ta 17.735 ve Yozgat'ta 9756 çalışan olduğu görülmektedir. Üç ilde de inşaat sektöründe çalışan sayısının 2010 yılına göre yükseldiği görülmektedir. İl toplam istihdamından inşaat sektörünün aldığı pay incelendiğinde Kayseri' de \% 14,50, Sivas'ta \%22,29 ve Yozgat'ta \%23,53 olduğu görülmektedir. 2015 yılında üç ilde inşaat sektöründe sigortalı çalışanların TR72 Bölgesinde toplam istihdamdan aldığı pay incelendiğinde \%17,40 olduğu görülmektedir. 
Baş, M.B. \& Ergen, B., (2021). TR72 bölgesinde il düzeyinde inşaat-sanayi ve hizmetler sektörü yı̆̆ımasinın lokasyon katsayısı yöntemiyle araştırılması.

\section{Tablo 3}

TR72 Bölgesindeki İnşaat Sektörünün Sigortalı Çalışan Sayıları (2015)

\begin{tabular}{ccccc}
\hline IIller & $\begin{array}{c}\text { İnşaat Sektörü } \\
\text { İstihdamı (iL) }\end{array}$ & $\begin{array}{c}\text { İnşaat Sektörü } \\
\text { İstihdam (TR72) }\end{array}$ & $\begin{array}{c}\text { Toplam İstihdam } \\
\text { (ILL) }\end{array}$ & $\begin{array}{c}\text { Toplam İstihdam } \\
\text { (TR72) }\end{array}$ \\
\hline Kayseri & 32.130 & & 221.581 & \\
Sivas & 17.735 & & 79.542 & \\
Yozgat & 9.756 & & 41.451 & \\
\hline TR72 Bölgesi & & 59.621 & & 342.574 \\
\hline
\end{tabular}

Kaynak: SGK yıllık iş faaliyet gruplarına göre zorunlu sigortalı çalışan sayısı verileri

TR72 Bölgesinde 2015 yılı sigortalı çalışan sayılarına göre Kayseri, Sivas ve Yozgat illerinde inşaat sektörü lokasyon katsayısı hesaplandığında Kayseri'de 0,83, Sivas'ta 1,28 ve Yozgat'ta 1,35 olduğu görülmektedir. Şekil 2'de TR72 Bölgesinde inşaat sektöründe yığıllma durumu gösterilmiştir. Yozgat ve Sivas illerinde inşaat sektöründe yığılma olduğu görülmektedir.

\section{Şekil 2}

TR72 Bölgesi İnşaat Sektöründe Yı̆̆ılma (2015)

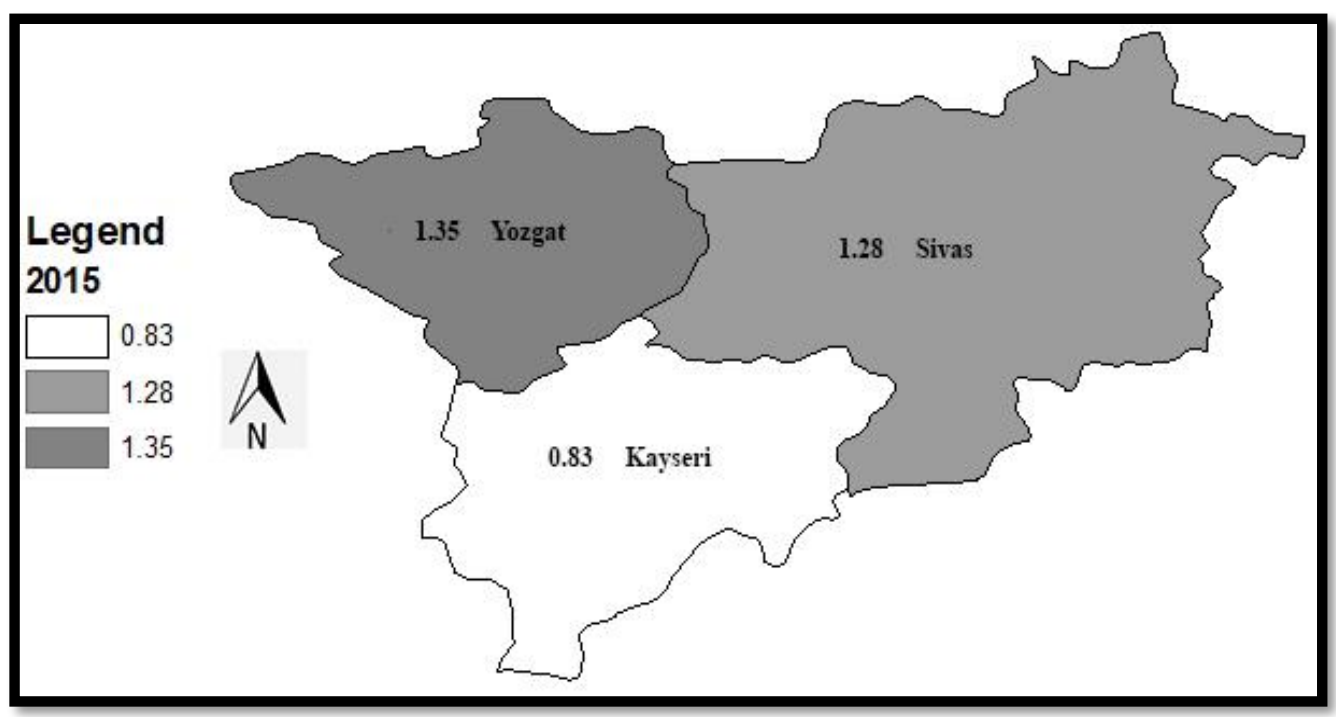

Kaynak: Bu çalışmadan esas alınarak yazar tarafindan oluşturulmuştur.

Tablo 4 incelendiğinde, 2019 y1lında TR72 Bölgesinde sigortalı toplam istihdam 333.065 kişi olduğu ve 2015 yılına göre 9509 kişi azaldığ görülmektedir. 2019 yılında ise yılı inşaat sektörü sigortalı çalışan sayıları verisi incelendiğinde Kayseri'de 18.505 , Sivas'ta 8.385 ve Yozgat'ta 5.722 çalışan olduğu görülmektedir. Üç ilde de inşaat sektöründe çalışan sayısının azaldığı görülmektedir. İl toplam istihdamından inşaat sektörünün aldığı pay incelendiğinde Kayseri'de $\% 8,40$, Sivas'ta $\% 11,55$ ve Yozgat'ta \%14,23 olduğu görülmektedir. 2019 yılında üç ilde inşaat sektöründe sigortalı çalışanların TR72 Bölgesinin toplam istihdamından aldığı pay incelendiğinde $\% 9,79$ olduğu görülmektedir. 
Kayseri Üniversitesi Sosyal Bilimler Dergisí Cilt 3, Sayi: 1, Haziran 2021, 41-59

Kayseri University Journal of Social Sciences. Vol 3, NNo: 1, June 2021, 41-59

\section{Tablo 4}

TR72 Bölgesindeki İnşaat Sektörünün Sigortalı Çalışan Sayıları (2019)

\begin{tabular}{ccccc}
\hline İller & $\begin{array}{c}\text { İnşaat Sektörü } \\
\text { İstihdamı (IL) }\end{array}$ & $\begin{array}{c}\text { İnşaat Sektörü } \\
\text { İstihdamı (TR72) }\end{array}$ & $\begin{array}{c}\text { Toplam İstihdam } \\
\text { (IL) }\end{array}$ & $\begin{array}{c}\text { Toplam İstihdam } \\
\text { (TR72) }\end{array}$ \\
\hline Kayseri & 18.505 & & 220.267 & \\
Sivas & 8.385 & & 72.591 & \\
Yozgat & 5.722 & & 40.207 & \\
\hline Tr72 Bölgesi & & 32.612 & & 333.065 \\
\hline
\end{tabular}

Kaynak: SGK yıllık iş faaliyet gruplarına göre zorunlu sigortalı çalışan sayısı verileri

Şekil 3 incelendiğinde TR72 Bölgesinin 2019 yılında inşaat sektöründe yı̆̆ılma düzeyi görülmektedir. Tablo 4 verilerine göre inşaat sektöründe sigortalı çalışan sayıları esas alındığında lokasyon katsayısının Kayseri'de 0,86, Sivas'ta 1,18 ve Yozgat'ta 1,45 olduğu ve Yozgat ve Sivas illerinde inşaat sektöründe yığglma olduğu dikkati çekmektedir.

\section{Şekil 3}

TR72 Bölgesi İnşaat Sektöründe Yı̆̆llma (2019)



Kaynak: Bu çalışmadan esas alınarak yazar tarafından oluşturulmuştur.

\section{Sanayi sektöründe yığılma (2010-2015-2019):}

Tablo 5 TR72 Bölgesinde sanayi sektörü, toplam istihdam, il bazında sanayi sektörü ve illerde toplam istihdam verilerini göstermektedir. Tablo 5 verilerine göre, 2010 y1lında TR72 Bölgesinde sigortalı çalışan sayısı 248.834 kişidir. 2010 yılı sanayi sektörü sigortalı çalışan sayıları verisi incelendiğinde Kayseri'de 55.029, Sivas'ta 11.151 ve Yozgat'ta 6.940 kişinin sanayi sektöründe çalıştığı görülmektedir. İl toplam istihdamından sanayi sektörünün aldığı pay incelendiğinde Kayseri'de $\% 34,17$, Sivas'ta \%20,03, Yozgat'ta \%21,56 olduğu görülmektedir. 2010 y1lında üç ilde sanayi 
Baş, M.B. \& Ergen, B., (2021). TR72 bölgesinde il düzeyinde inşaat-sanayi ve hizmetler sektörü yı̆̆ımasinın lokasyon katsayısı yöntemiyle araştırılması.

sektöründe sigortalı çalışanların TR72 Bölgesinde toplam istihdamdan aldığı pay incelendiğinde $\% 29,38$ olduğu görülmektedir.

\section{Tablo 5}

TR72 Bölgesindeki Sanayi Sektörünün Sigortalı Çalışan Sayıları (2010)

\begin{tabular}{ccccc}
\hline Iller & $\begin{array}{c}\text { Sanayi Sektörü } \\
\text { İstihdamı (II) }\end{array}$ & $\begin{array}{c}\text { Sanayi Sektörü } \\
\text { İstihdamı (Tr72) }\end{array}$ & $\begin{array}{c}\text { Toplam } \\
\text { İstihdam (il) }\end{array}$ & $\begin{array}{c}\text { Toplam İstihdam } \\
\text { (TR72) }\end{array}$ \\
\hline Kayseri & 55.029 & & 161.004 & \\
Sivas & 11.151 & & 55.649 & \\
Yozgat & 6.940 & & 32.181 & \\
\hline TR72 Bölgesi & & 73.120 & & 248.834 \\
\hline
\end{tabular}

Kaynak: SGK yıllık iş faaliyet gruplarına göre zorunlu sigortalı çalışan sayısı verileri

Tablo 5 verileri esas alınarak hesaplanan lokasyon katsayısı sonuçları şekil 4'te görülmektedir. 2010 yılı sanayi sektöründe yığılma hesaplandığında Kayseri'de 1,16, Yozgat'ta 0,73 ve Sivas'ta 0,68 olduğu görülmektedir. Sadece Kayseri'de lokasyon katsayısının 1 değerinin üzerinde olması nedeniyle sanayi sektöründe yığılma olduğu görülmektedir.

\section{Şekil 4}

TR72 Bölgesi Sanayi Sektöründe Yiğglma (2010)

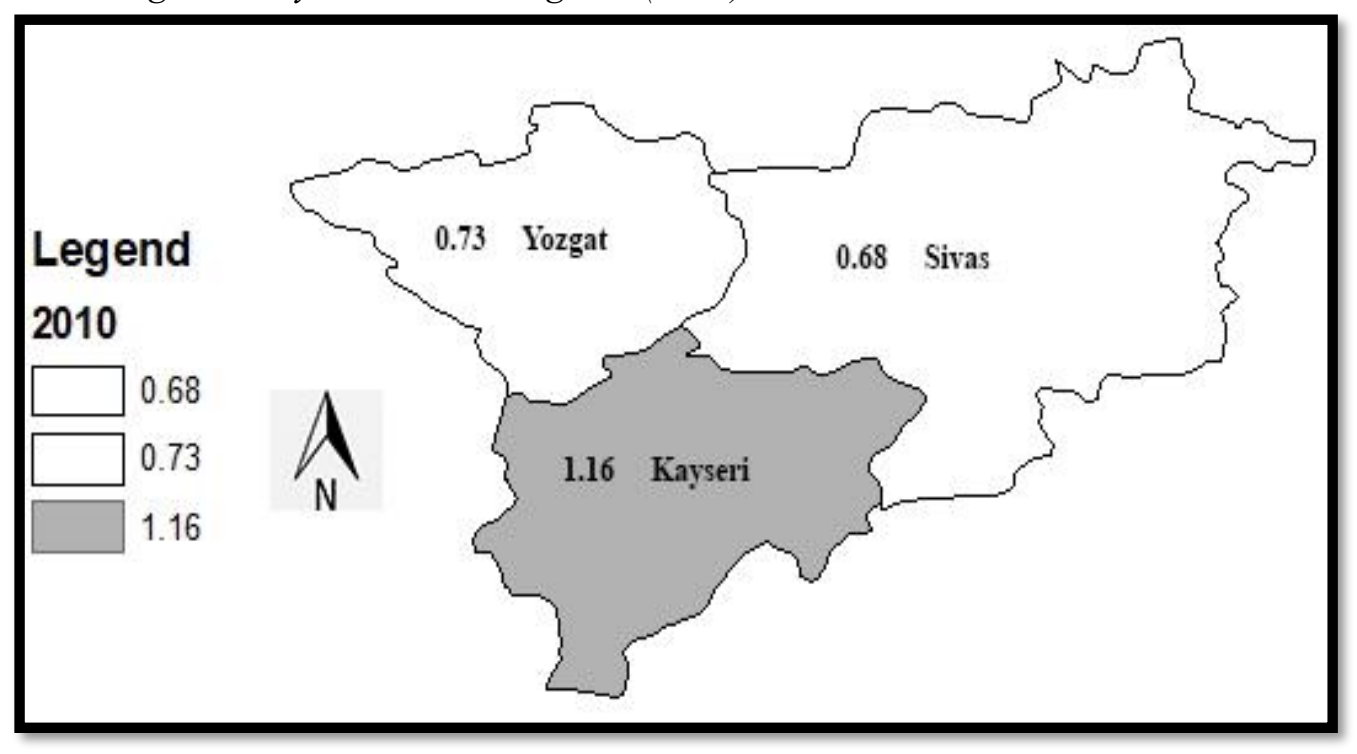

Kaynak: Bu çalışmadan esas alınarak yazar tarafından oluşturulmuştur.

Tablo 6 incelendiğinde, 2015 yılında TR72 Bölgesinde sigortalı toplam istihdam 342.574 kişi olduğu ve 2010 yılına göre 93.740 kişi artış gösterdiği görülmektedir. 2015 yılında ise yılı sanayi sektörü sigortalı çalışan sayıları verisi incelendiğinde Kayseri'de 72.790, Sivas'ta 14.256 ve Yozgat'ta 6.891 çalışan olduğu görülmektedir. Kayseri ve Sivas'ta sanayi sektöründe çalışan sayısının 2010 yılına göre artış gösterdiği; Yozgat'ta ise 2010 yılına göre sanayi sektöründe sigortalı çalışan sayısının azaldığı görülmektedir. İl toplam istihdamından sanayi sektörünün aldığı pay incelendiğinde Kayseri'de $\% 32,85$, Sivas’ta \%17,92 ve Yozgat’ta \%16,62 olduğu görülmektedir. 2015 yılında üç ilde inşaat sektöründe 
Kayseri Üniversitesi Sosyal Bilimler Dergisí Cilt 3, Sayi: 1, Haziran 2021, 41-59

Kayseri University Journal of Social Sciences. Vol 3, NNo: 1, June 2021, 41-59

sigortalı çalışanların TR72 Bölgesinde toplam istihdamdan aldığı pay incelendiğinde $\% 27,42$ olduğu görülmektedir.

\section{Tablo 6}

TR72 Bölgesindeki Sanayi Sektörünün Sigortalı Çalışan Sayıları (2015)

\begin{tabular}{ccccc}
\hline İler & $\begin{array}{c}\text { Sanayi Sektörü } \\
\text { İstihdam (iL) }\end{array}$ & $\begin{array}{c}\text { Sanayi Sektörü } \\
\text { İstihdam (TR72) }\end{array}$ & $\begin{array}{c}\text { Toplam } \\
\text { İstihdam (IL) }\end{array}$ & $\begin{array}{c}\text { Toplam İstihdam } \\
\text { (TR72) }\end{array}$ \\
\hline Kayseri & 72.790 & & 221.581 & \\
Sivas & 14.256 & & 79.542 & \\
Yozgat & 6.891 & & 41.451 & \\
\hline TR72 Bölgesi & & 93.937 & & 342.574 \\
\hline
\end{tabular}

Kaynak: SGK yıllık iş faaliyet gruplarına göre zorunlu sigortalı çalışan sayısı verileri

Tablo 6 verileri esas alınarak lokasyon katsayısı hesaplandığında 2015 yılında sanayi sektöründe yığılma düzeyi Kayseri'de 1,2, Sivas'ta 0,65 ve Yozgat'ta 0,61 olduğu görülmektedir. Şekil 5 sanayi sektöründe sigortalı çalışanlara göre 2015 yılına ait lokasyon katsayısı hesabını göstermektedir. Lokasyon katsayısının 1 değeri üzerinde olan tek ile Kayseri'dir ve Kayseri’de sanayi sektöründe yığılma olduğu görülmektedir.

\section{Şekil 5}

\section{TR72 Bölgesi Sanayi Sektöründe Ylğılma (2015)}

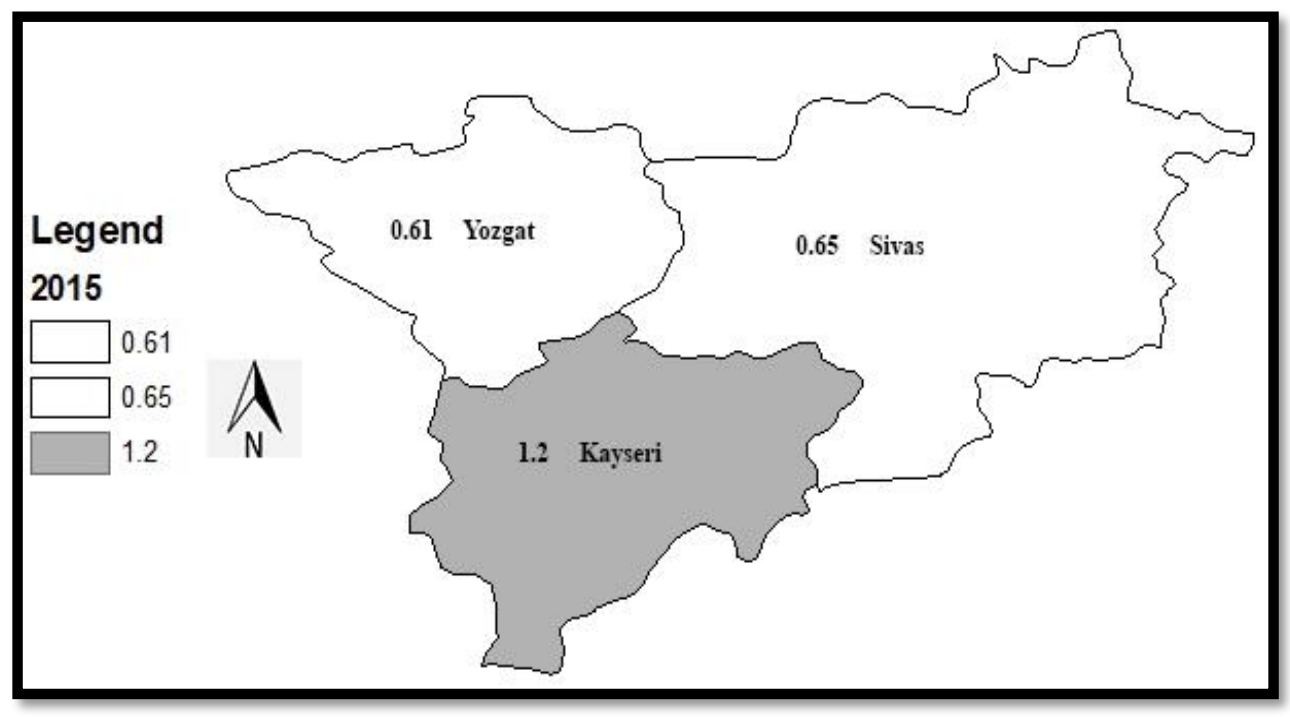

Kaynak: Bu çalışmadan esas alınarak yazar tarafindan oluşturulmuştur.

Tablo 7 incelendiğinde, 2019 yılında TR72 Bölgesinde sigortalı toplam istihdamın 333.065 kişi olduğu ve 2015 yılına göre 9.509 kişi azaldığı görülmektedir. 2019 yılı sanayi sektörü sigortalı çalışan sayıları verisi incelendiğinde Kayseri'de 74.638, Sivas'ta 12.429 ve Yozgat'ta 6.671 çalışan olduğu görülmektedir. 2015 yılı verilerine göre, Kayseri'de sanayi sektöründe sigortalı çalışan sayısının artığı, Yozgat ve Sivas'ta sanayi sektöründe sigortalı çalışan sayısının azaldığı görülmektedir. İl toplam istihdamından sanayi sektörünün aldığı pay incelendiğinde Kayseri’de $\% 33,88$, Sivas'ta $\% 17,12$ ve 
Baş, M.B. \& Ergen, B., (2021). TR72 bölgesinde il düzeyinde inşaat-sanayi ve hizmetler sektörü yı̆̆ımasinın lokasyon katsayısı yöntemiyle araştırılması.

Yozgat'ta \%16,59 olduğu görülmektedir. 2015 y1lında üç ilde inşaat sektöründe sigortalı çalışanların TR72 Bölgesinde toplam istihdamdan aldığı pay incelendiğinde $\% 28,14$ olduğu görülmektedir.

\section{Tablo 7}

TR72 Bölgesindeki Sanayi Sektörünün Sigortalı Çalışan Sayıları (2019)

\begin{tabular}{ccccc}
\hline İLLER & $\begin{array}{c}\text { Sanayi Sektörü } \\
\text { İstihdam (IL) }\end{array}$ & $\begin{array}{c}\text { Sanayi Sektörü } \\
\text { İstihdam (TR72) }\end{array}$ & $\begin{array}{c}\text { Toplam } \\
\text { İstihdam (IL) }\end{array}$ & $\begin{array}{c}\text { Toplam İstihdam } \\
\text { (TR72) }\end{array}$ \\
\hline Kayseri & 74.638 & & 220.267 & \\
Sivas & 12.429 & & 72.591 & \\
Yozgat & 6.671 & & 40.207 & \\
\hline TR72 Bölgesi & & 93.738 & & 333.065 \\
\hline
\end{tabular}

Kaynak: SGK yıllık iş faaliyet gruplarına göre zorunlu sigortalı çalışan sayısı verileri

Tablo 7 verileri esas alınarak 2019 yılı sanayi sektörü lokasyon katsayıs1 Kayseri'de 1,20, Sivas'ta 0,61 ve Yozgat'ta 0,59 olarak hesaplanmaktadır. Şekil 6, sanayi sektöründe sigortalı çalışanlara göre 2019 yılına ait lokasyon katsayısı hesabını göstermektedir. Lokasyon katsayısının 1 değeri üzerinde olduğu Kayseri’de sanayi sektöründe yığılma olduğu görülmektedir.

\section{Şekil 6}

TR72 Bölgesi Sanayi Sektöründe Yiğılma (2019)

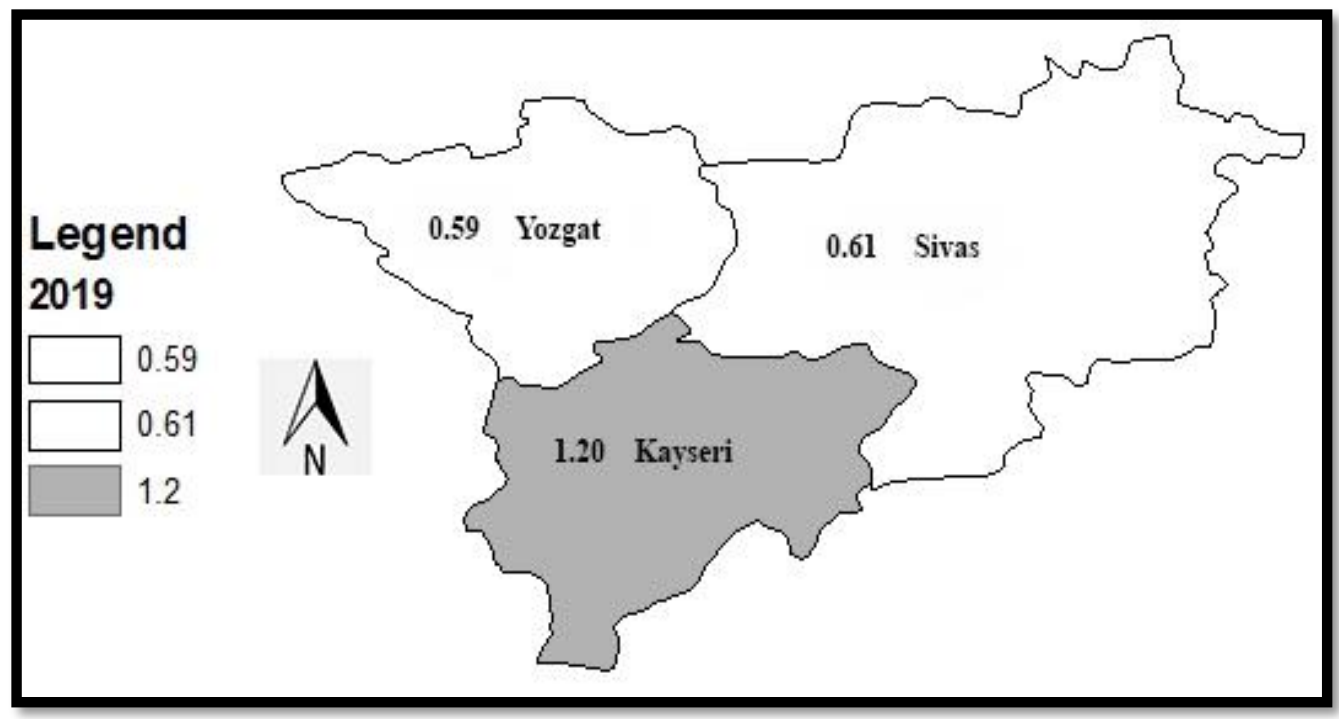

Kaynak: Bu çalışmadan esas alınarak yazar tarafından oluşturulmuştur.

\section{Hizmetler sektöründe yığılma (2010-2015-2019):}

Tablo 8 TR72 Bölgesinde hizmet sektörü ve toplam istihdam ile il bazında hizmetler sektörü ve illerde toplam istihdam verilerini göstermektedir. Tablo 8 verilerine göre, 2010 y1lında TR72 Bölgesinde sigortalı çalışan sayısı 248.834 kişidir. 2010 yılı hizmetler sektörü sigortalı çalışan sayıları verisi incelendiğinde Kayseri'de 39.691, Sivas'ta 14.288 ve Yozgat'ta 8.294 kişi çalıştığ görülmektedir. İl toplam istihdamından inşaat sektörünün aldığı pay incelendiğinde Kayseri'de $\% 24,65$, Sivas'ta $\% 25,67$, 
Kayseri Üniversitesi Sosyal Bilimler Dergisí Cilt 3, Sayi: 1, Haziran 2021, 41-59

Kayseri University Journal of Social Sciences. Vol 3, NNo: 1, June 2021, 41-59

Yozgat'ta \%25,77 olduğu görülmektedir. 2010 yılında üç ilde hizmetler sektöründe sigortalı çalışanların TR72 Bölgesinde toplam istihdamdan aldığı pay incelendiğinde $\% 25,02$ olduğu görülmektedir.

\section{Tablo 8}

TR72 Bölgesindeki Hizmetler Sektörünün Sigortalı Çalışan Sayıları (2010)

\begin{tabular}{ccccc}
\hline İller & $\begin{array}{c}\text { Hizmetler } \\
\text { Sektörü } \\
\text { İstihdam (IL) }\end{array}$ & $\begin{array}{c}\text { Toplam Hizmetler } \\
\text { Sektörü İstihdam } \\
\text { (TR72) }\end{array}$ & $\begin{array}{c}\text { Toplam } \\
\text { İstihdam } \\
\text { (IL) }\end{array}$ & $\begin{array}{c}\text { Toplam } \\
\text { İstihdam } \\
\text { (TR72) }\end{array}$ \\
\hline Kayseri & 39.691 & & 161.004 & \\
Sivas & 14.288 & & 55.649 & \\
Yozgat & 8.294 & & 32.181 & \\
\hline TR72 Bölgesi & & 62.273 & & 248.834 \\
\hline
\end{tabular}

Kaynak: SGK yıllık iş faaliyet gruplarına göre zorunlu sigortalı çalışan sayısı verileri

Tablo 8 verileri esas alınarak lokasyon katsayısı 2010 yılında Kayseri'de 0,99, Sivas'ta 1,03 ve Yozgat'ta 1,03 olarak hesaplanmaktadır. Şekil 7 hizmetler sektöründe sigortalı çalışanlara göre 2010 y1lı lokasyon katsayısı hesabını göstermektedir. Lokasyon katsayısının 1 değeri üzerinde Sivas ve Yozgat illerinde olduğu ve hizmetler sektöründe yığılma olduğu görülmektedir.

\section{Şekil 7}

\section{TR72 Bölgesi Hizmetler Sektöründe Yiğglma (2010)}

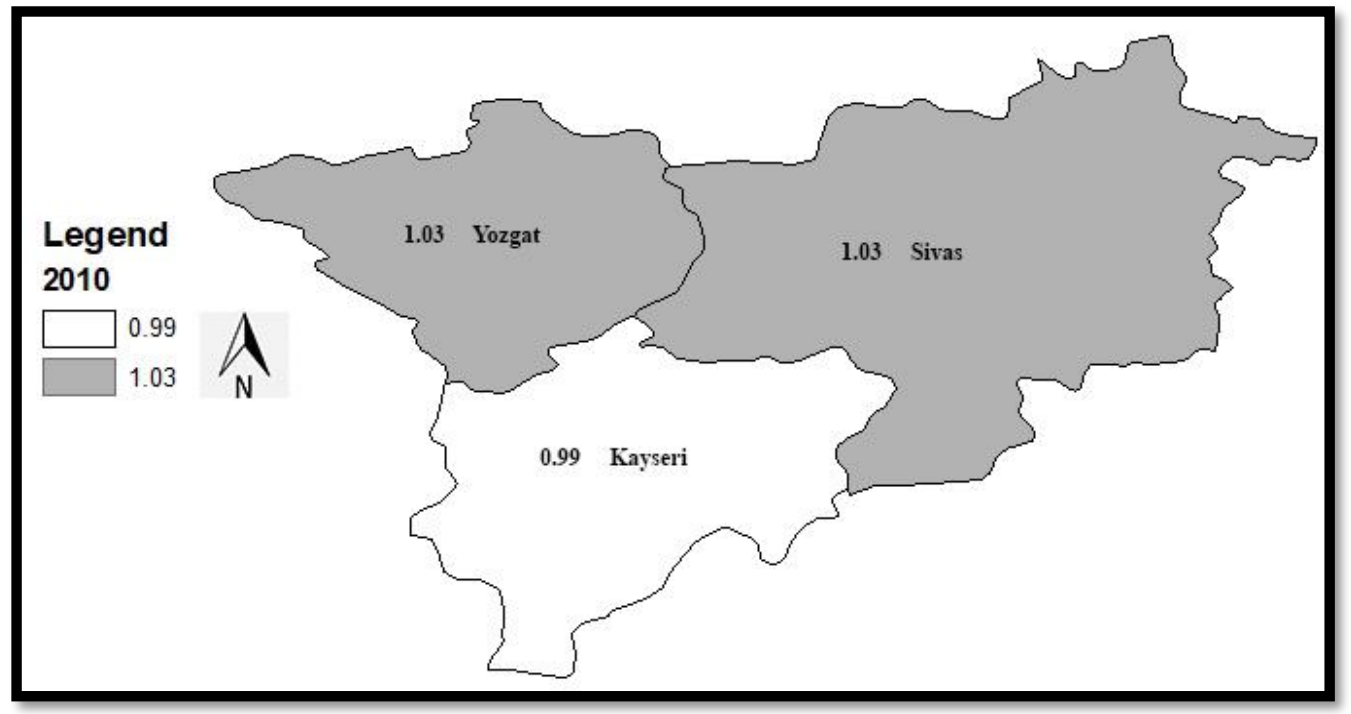

Kaynak: Bu çalışmadan esas alınarak yazar tarafından oluşturulmuştur.

Tablo 9 incelendiğinde, 2015 yılında TR72 Bölgesinde sigortalı toplam istihdam 342.574 kiși olduğu ve 2010 yılına göre 93.740 kişi artış gösterdiği görülmektedir. 2015 y1lında ise hizmetler sektörü sigortalı çalışan sayıları verisi incelendiğinde Kayseri'de 63.680, Sivas'ta 25.282 ve Yozgat'ta 14.016 çalışan olduğu görülmektedir. Üç ilde de hizmetler sektöründe çalışan sayısının 2010 yılına göre arttığ 1 görülmektedir. İl toplam istihdamından hizmetler sektörünün aldığı pay incelendiğinde Kayseri'de 
Baş, M.B. \& Ergen, B., (2021). TR72 bölgesinde il düzeyinde inşaat-sanayi ve hizmetler sektörü yı̆̆ımasinın lokasyon katsayısı yöntemiyle araştırılması.

$\% 28,73$, Sivas'ta \%31,78 ve Yozgat'ta \%33,81 olduğu görülmektedir. 2015 y1lında üç ilde inşaat sektöründe sigortalı çalışanların TR72 Bölgesinde toplam istihdamdan aldığı pay incelendiğinde $\% 30,06$ olduğu görülmektedir.

\section{Tablo 9}

TR72 Bölgesindeki Hizmetler Sektörünün Sigortalı Çalışan Sayıları (2015)

\begin{tabular}{ccccc}
\hline Iller & $\begin{array}{c}\text { Hizmetler Sektörü } \\
\text { İstihdam (IL) }\end{array}$ & $\begin{array}{c}\text { Toplam Hizmetler } \\
\text { Sektörü İstihdam } \\
\text { (TR72) }\end{array}$ & $\begin{array}{c}\text { Toplam Sektörel } \\
\text { Istihdam (iL) }\end{array}$ & $\begin{array}{c}\text { Toplam Sektörel } \\
\text { İstihdam (TR72) }\end{array}$ \\
\hline Kayseri & 63.680 & & 221.581 & \\
Sivas & 25.282 & & 79.542 & \\
Yozgat & 14.016 & & 41.451 & \\
\hline TR72 Bölgesi & & 102.978 & & 342.574 \\
\hline
\end{tabular}

Kaynak: SGK yıllık iş faaliyet gruplarına göre zorunlu sigortalı çalışan sayısı verileri

Tablo 9 verileri esas alınarak lokasyon katsayısı 2015 yılında Kayseri'de 0,96, Sivas'ta 1,06 ve Yozgat'ta 1,12 olarak hesaplanmaktadır. Şekil 8, hizmetler sektöründe sigortalı çalışanlara göre 2015 yılı lokasyon katsayısı hesabını göstermektedir. Lokasyon katsayısının 1 değeri üzerinde Sivas ve Yozgat illerinde olduğu ve hizmetler sektöründe yığılma olduğu görülmektedir.

\section{Şekil 8}

TR72 Bölgesi Hizmetler Sektöründe Yiğllma (2015)

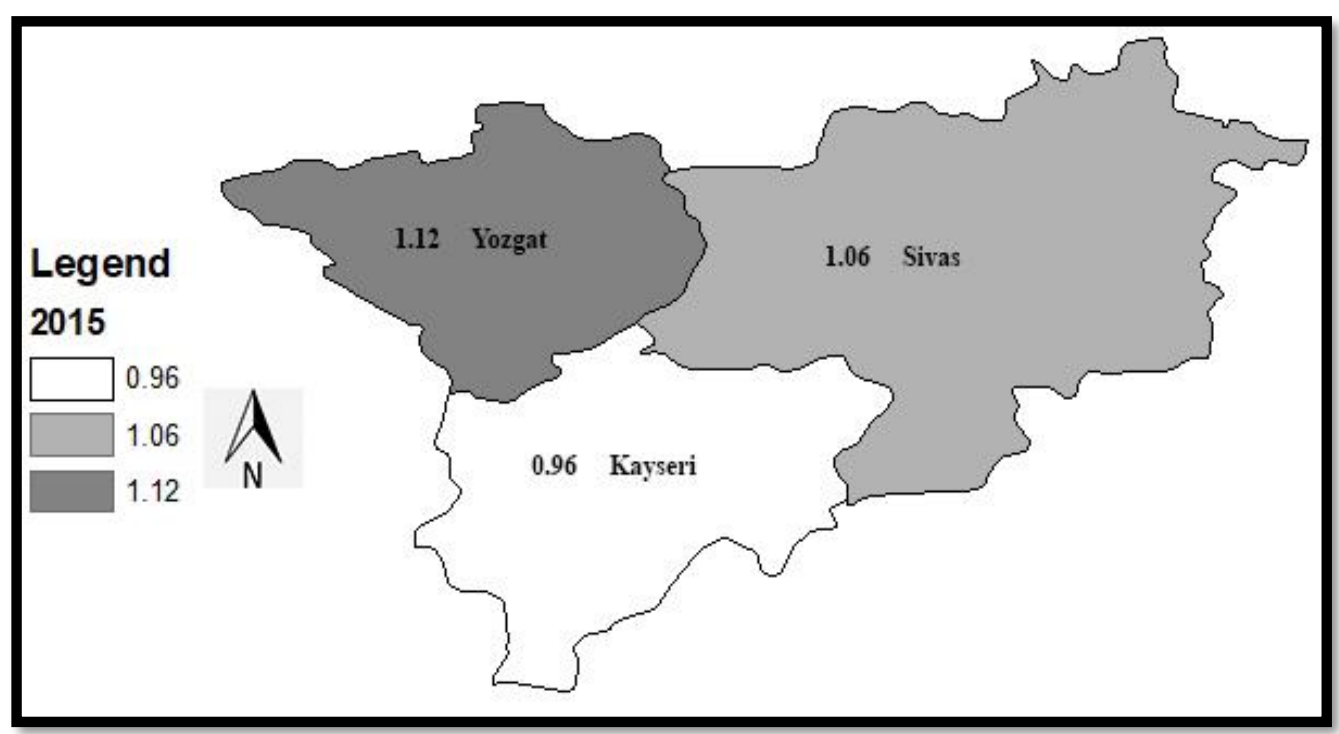

Kaynak: Bu çalı̧̧madan esas alınarak yazar tarafindan oluşturulmuştur.

Tablo 10 incelendiğinde, 2019 y1lında TR72 Bölgesinde sigortalı toplam istihdam 333.065 kişi olduğu ve 2015 yılına göre 9.509 kişi azaldığı görülmektedir. 2019 yılında ise hizmetler sektörü sigortalı çalışan sayıları verisi incelendiğinde Kayseri'de 73.305 , Sivas'ta 29.666 ve Yozgat'ta 17.659 çalışan olduğu görülmektedir. Üç ilde de hizmetler sektöründe çalışan sayısının 2015 yılına göre arttığı 
Kayseri Üniversitesi Sosyal Bilimler Dergisí Cilt 3, Sayi: 1, Haziran 2021, 41-59

Kayseri University Journal of Social Sciences. Vol 3, NNo: 1, June 2021, 41-59

görülmektedir. İl toplam istihdamından hizmetler sektörünün aldığı pay incelendiğinde Kayseri'de $\% 33,28$, Sivas'ta \%40,86 ve Yozgat'ta \%43,92 olduğu görülmektedir. 2019 y1lında üç ilde inşaat sektöründe sigortalı çalışanların TR72 Bölgesinde toplam istihdamdan aldığı pay incelendiğinde \%36,21 olduğu görülmektedir.

Tablo 10

TR72 Bölgesindeki Hizmetler Sektörünün Sigortalı Çalışan Sayıları (2019)

\begin{tabular}{ccccc}
\hline İller & $\begin{array}{c}\text { Hizmetler Sektörü } \\
\text { İstihdam (iL) }\end{array}$ & $\begin{array}{c}\text { Toplam Hizmetler } \\
\text { Sektörü İstihdam } \\
\text { (TR72) }\end{array}$ & $\begin{array}{c}\text { Toplam Sektörel } \\
\text { İstihdam (IL) }\end{array}$ & $\begin{array}{c}\text { Toplam Sektörel } \\
\text { İstihdam (TR72) }\end{array}$ \\
\hline Kayseri & 73.305 & & 220.267 & \\
Sivas & 29.666 & & 72.591 & \\
Yozgat & 17.659 & & 40.207 & \\
\hline TR72 Bölgesi & & 120.630 & & 333.065 \\
\hline
\end{tabular}

Kaynak: SGK yıllık iş faaliyet gruplarına göre zorunlu sigortalı çalışan sayısı verileri

Tablo 10 verileri esas alınarak lokasyon katsayısı hesaplandığında, 2019 yılında lokasyon katsayısı sonuçlarının Kayseri'de 0,92, Sivas'ta 1,13 ve Yozgat'ta 1,21 olduğu görülmektedir. Şekil 9, hizmetler sektöründe sigortalı çalışanlara göre 2019 yılı lokasyon katsayısı hesabını göstermektedir. Lokasyon katsayısının 1 değeri üzerinde Sivas ve Yozgat illerinde olduğu ve hizmetler sektöründe yığılmanın bu illerde olduğu görülmektedir.

\section{Şekil 9}

TR72 Bölgesi Hizmetler Sektöründe Yiğglma (2019)

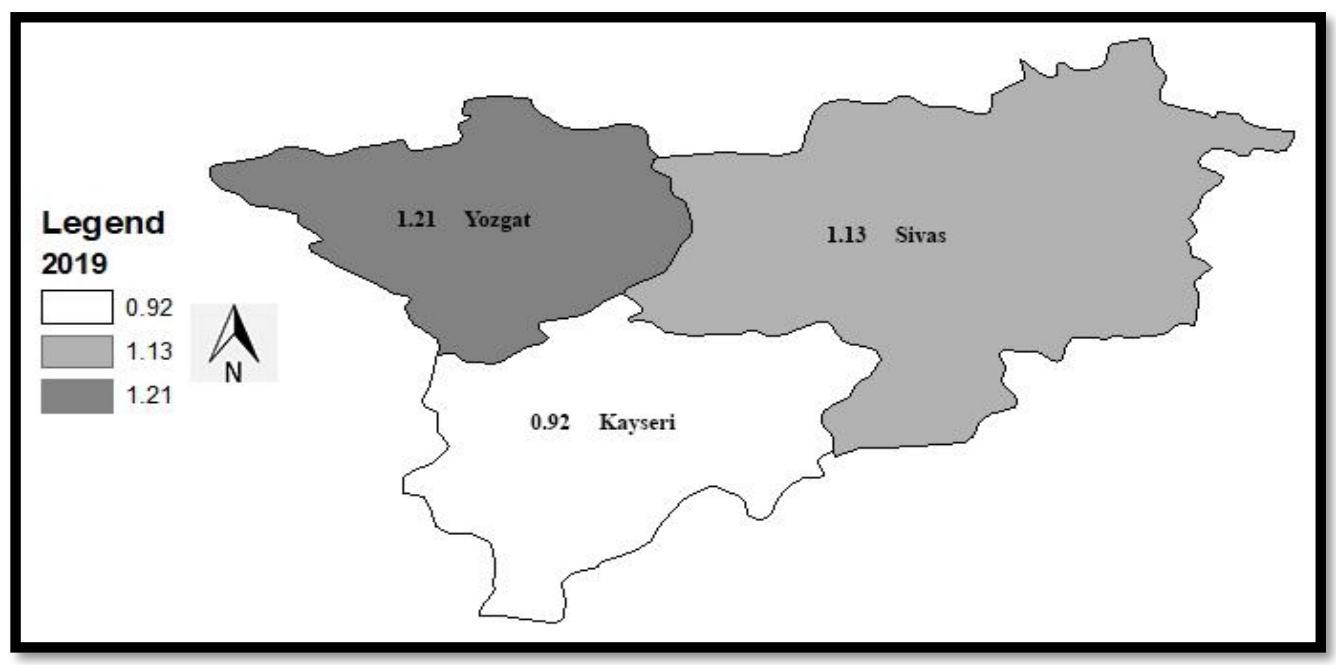

Kaynak: Bu çalışmadan esas alınarak yazar tarafından oluşturulmuştur.

\section{Tartışma ve sonuç}

TR72 Bölgesinde sigortalı çalışan sayısı açısından inşaat sektörü incelendiğinde 2010 yılından 2015 yılına kadar üç ilde de artış olduğu, fakat 2015-2019 döneminde üç ilde de inşaat sektöründe 
Baş, M.B. \& Ergen, B., (2021). TR72 bölgesinde il düzeyinde inşaat-sanayi ve hizmetler sektörü yı̆̆ımasinın lokasyon katsayısı yöntemiyle araştırılması.

çalışan sayılarının azaldığ görülmektedir. Şekil 10 inşaat sektöründe sigortalı çalışan sayılarının 20102015-2019 yıllarındaki artı̧̧ ve azalışını göstermektedir. İnşaat sektöründe olan bu azalma eğilimi gelecekte yapılacak planlarda TR72 Bölgesi için inşaat sektörüne hassas yaklaşılması gerektiğini göstermektedir.

\section{Şekil 10}

Kayseri-Sivas-Yozgat İnşaat Sektörü Sigortalı Çalışan Sayıları

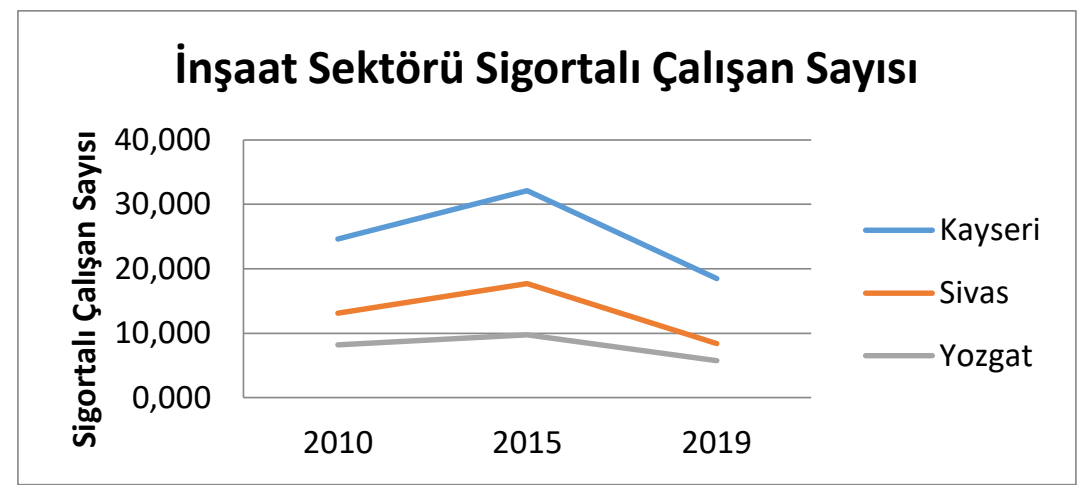

Kaynak: Bu çalışmadan esas alınarak yazar tarafından oluşturulmuştur.

Şekil 11 Kayseri, Sivas ve Yozgat'ta 2010-2015-2019 yıllarında inşaat sektörü lokasyon katsayısı değerlerini göstermektedir. İnşaat sektöründe yığılma durumu incelendiğinde Yozgat ve Sivas illerinde yığılma özelliği gösterdiği, Kayseri' de yığılma özelliği göstermediği görülmektedir. Yozgat'in inşaat sektöründe yoğunlaşma başladığı ve baskın hale geldiği söylenebilir. Sivas'ın ise yoğunlaşma durumunda düşüş eğilimi olduğu görülmektedir.

\section{Şekil 11}

Kayseri-Sivas-Yozgat İnşaat Sektörü LQ

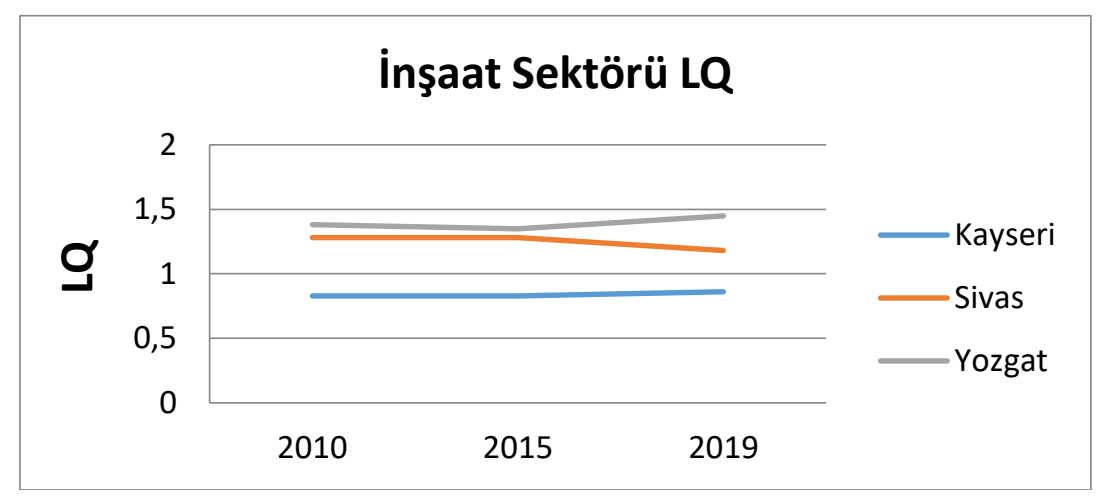

Kaynak: Bu çalışmadan esas alınarak yazar tarafindan oluşturulmuştur.

Şekil 12 Kayseri, Sivas ve Yozgat'ta 2010-2015-2019 yıllarında sanayi sektöründe sigortalı çalışan sayılarını göstermektedir. Sanayi sektörü sigortalı çalışan sayıları incelendiğinde Kayseri'de 2015 yılına kadar artış olduğu, 2019 yılında da artışın devam ettiği fakat artış eğiliminde azalma olduğu dikkati çekmektedir. Sanayi sektörü açısından Kayseri'nin yavaş yavaş doygunluk seviyesine doğru geldiği söylenebilir. Bu noktada gelecek dönemlerde yapılacak planlarda eğer sanayi sektörü ağırlıklı 
Kayseri Üniversitesi Sosyal Bilimler Dergisí Cilt 3, Sayi: 1, Haziran 2021, 41-59

Kayseri University Journal of Social Sciences. Vol 3, NNo: 1, June 2021, 41-59

bir yaklaşım benimsenecekse yeni sanayi yatırımlarını teşvik edecek plan kararlarına ihtiyaç duyulduğu söylenebilir.

\section{Şekil 12}

Kayseri-Sivas-Yozgat Sanayi Sektörü Sigortalı Çalışan Sayıları



Kaynak: Bu çalışmadan esas alınarak yazar tarafından oluşturulmuştur.

Şekil 13 Kayseri, Sivas ve Yozgat'ta 2010-2015-2019 y1llarında sanayi sektöründe lokasyon katsayısı verilerini göstermektedir. Sanayi sektöründe yığılma özelliğinin belirlenmesi için 2010-20152019 yıllarında lokasyon katsayısı hesaplandığında yığılma özelliğinin sadece Kayseri'de olduğu görülmektedir. Kayseri iş gücü açısından sanayi yatırımı yapılabilecek potansiyele sahiptir. Yozgat ve Sivas ise iş gücü açısından yığılma özelliği göstermediği gibi, sanayi sektöründe yığıllma oranının düşüş eğiliminde olduğu görülmektedir. Yozgat ve Sivas'a yeni sanayi yatırımı planlamanın risk içerdiği gözden kaçırılmamalıdır.

\section{Şekil 13}

Kayseri-Sivas-Yozgat Sanayi Sektörü LQ

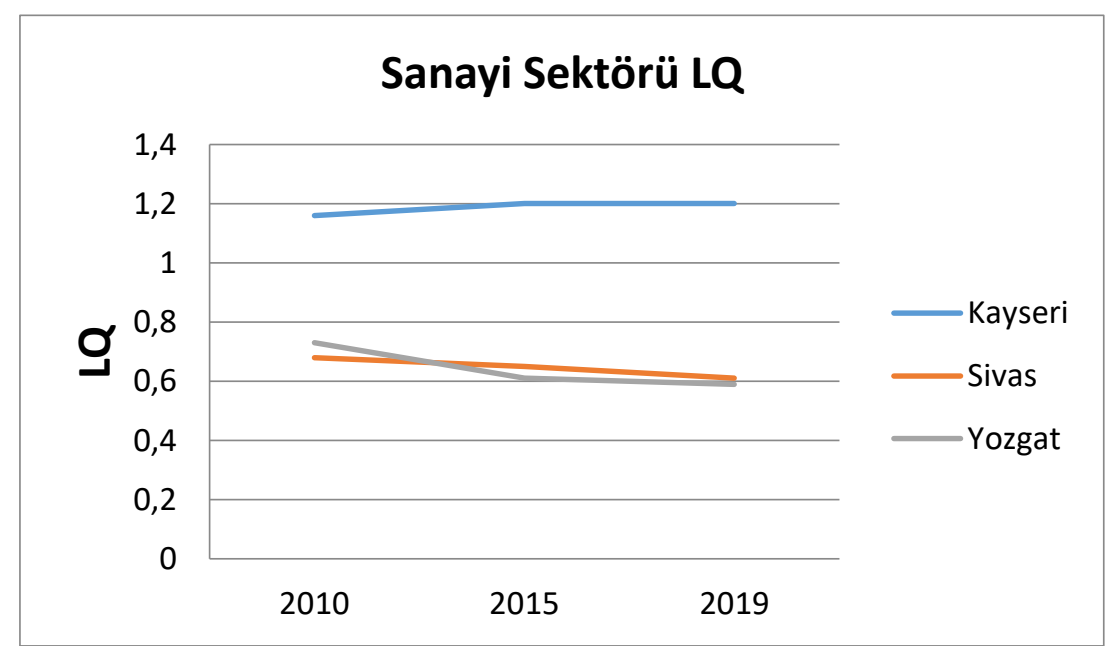

Kaynak: Bu çalışmadan esas alınarak yazar tarafindan oluşturulmuştur. 
Baş, M.B. \& Ergen, B., (2021). TR72 bölgesinde il düzeyinde inşaat-sanayi ve hizmetler sektörü yı̆̆ımasinın lokasyon katsayısı yöntemiyle araştırılması.

Şekil 14'te Hizmetler sektöründe Kayseri, Sivas ve Yozgat'ta 2010-2015-2019 y1llarında sigortalı çalışan sayısının sürekli artış eğiliminde olduğu görülmektedir. Artış hızı 2015 yılından sonra azalsa da hizmetler sektöründe artışın devam ettiği görülmektedir. Hizmetler sektörü TR72 Bölgesinde gelecekte planlama kararlarında başat rol oynayacaktır.

\section{Şekil 14}

Kayseri-Sivas-Yozgat Sanayi Sektörü Sigortalı Çalışan Sayıları

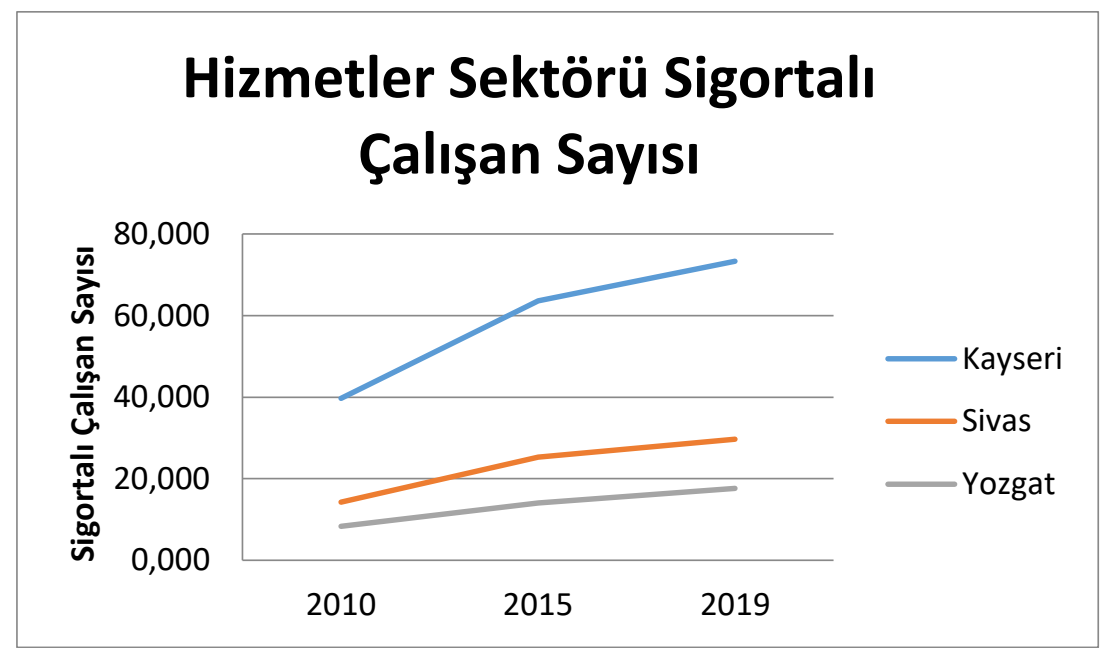

Kaynak: Bu çalışmadan esas alınarak yazar tarafından oluşturulmuştur.

Şekil 15 Kayseri, Sivas ve Yozgat'ta 2010-2015-2019 yıllarında hizmetler sektörü lokasyon katsayısı hesaplarını göstermektedir. Hizmetler sektöründe yığılma durumu incelendiğinde Yozgat ve Sivas illerinde yığılma özelliği görüldüğü ve artış eğiliminde olduğu dikkati çekmektedir. Kayseri'de ise çalışan sayısında artış olmasına rağmen yığılma oranının düşüş eğiliminde olduğu görülmektedir.

\section{Şekil 15}

Kayseri-Sivas-Yozgat Hizmetler Sektörü LQ

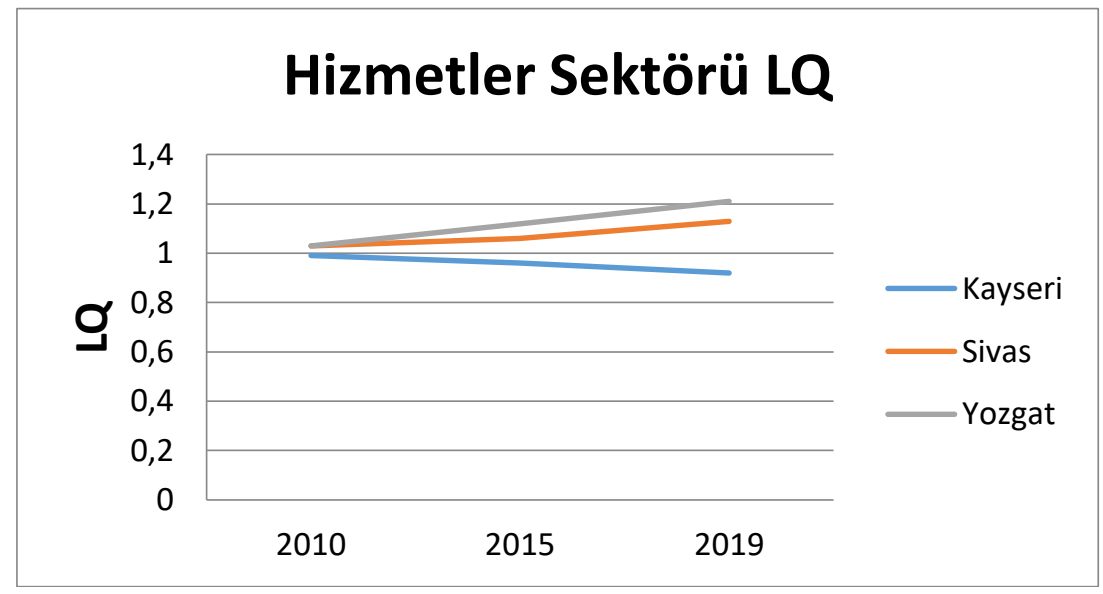

Kaynak: Bu çalışmadan esas alınarak yazar tarafından oluşturulmuştur. 
Kayseri Üniversitesi Sosyal Bilimler Dergisí Cilt 3, Sayi: 1, Haziran 2021, 41-59

Kayseri University Journal of Social Sciences. Vol 3, NNo: 1, June 2021, 41-59

TR72 Bölgesinde inşaat, sanayi ve hizmetler sektöründe sektörel yı ğılma araştırması sonucunda 2010-2019 yılları arasında Kayseri, Sivas ve Yozgat'ta mevcut eğilimlerin devam ettiği Kayseri'de sanayi yığılmasının, Yozgat ve Sivas'ta ise inşaat ve hizmetler sektöründe yığılma özelliği olduğu görülmektedir. Kent ekonomisi kentlerin büyümesinde önemli bir faktördür. Kentlerdeki başat sektörün, iş gücü piyasasının belirlenmesinin gelecekte yapılacak yatırımların planlanmasında ve yatırım kararlarının verilmesinde önemli rolü bulunmaktadır. Bu veriler bağlamında Yozgat'ta hizmetler ve inşaat sektörü geliştirilebilir sektörler olarak karşımıza çıkmaktadır. Kayseri’de sanayi sektörü yığılmasının rekabet edebilir seviyede olduğu görülmektedir. Sivas'ın ise inşaat sektöründe yığılması bulunmasına rağmen son dönemde düşüş göstermesi rekabetçilik açısından üzerinde durulması gereken bir noktadır. Sivas'ta hizmetler sektörü gelişen bir sektör olarak rekabet edebilir seviyeye doğru ilerlediği görülmektedir.

\section{Araştırmanın etik yönü}

Yapılan bu çalışmada "Yükseköğretim Kurumları Bilimsel Araştırma ve Yayın Etiği Yönergesi" kapsamında uyulması belirtilen tüm kurallara uyulmuştur. Yönergenin ikinci bölümü olan "Bilimsel Araştırma ve Yayın Etiğine Aykırı Eylemler" başlığı altında belirtilen eylemlerden hiçbiri gerçekleştirilmemiştir. Etik kurul izni gerektirmeyen çalışmalardandır.

\section{7. Çıkar çatışması beyanı}

Çalışmanın sonuçları veya yorumları etkileyebilecek herhangi bir maddi veya diğer asli çıkar çatışması olmadığını beyan ederiz.

\section{Katkı oranı}

Çalışmanın yazarları olarak makaleye eşit oranda katkı sağlamış olduğumuzu beyan ederiz.

\section{KAYNAKÇA}

Akgüngör, S. (2006). Geographic concentrations in Turkey's manufacturing industry: Identifying regional highpoint clusters. European Planning Studies, 14(2), 169-197. https://doi.org/10.1080/09654310500418002

Bottazzi, G., \& Gragnolati, U. (2015). Cities and clusters: economy- wide and sector-specific effects in corporate location. Regional Studies, 49(1), 113-129. https://doi.org/10.1080/00343404 .2012 .739281

Crawley, A., Beynon, M. \& Munday, M. (2013). Making location quotients more relevant as a policy aid in regional spatial analysis. Urban Studies, 50(9), 1854-1869.

Cromley, R.G., \& Hanink, D.M. (2012). Focal location quotients: Specification and applications. Geographical Analysis, 44(4), 398-410.

Çiftçi, M. (2018). Türkiye’ de bölgelerarası sektörel verimliliğim analizi. İşletme Araştırmalar Dergisi, 10(1), 551 - 580. https://doi.org/10.20491/isarder.2018.407 
Baş, M.B. \& Ergen, B., (2021). TR72 bölgesinde il düzeyinde inşaat-sanayi ve hizmetler sektörü yı̆̆ılmasının lokasyon katsayısı yöntemiyle araştırılması.

Demirdöğen, S. (2018). Kümelenme potansiyeli gösteren sektörlerin belirlenmesi: TRA 1 Düzey 2 Bölgesi üzerine bir uygulama. Bolu Abant İzzet Baysal Üniversitesi Sosyal Bilimler Enstitüsü Dergisi, 18 (4) , 85-113 . https://doi.org/10.11616/asbed.v18i41997.505856

Dîrzu, M. (2012). A conceptual approach to economic agglomerations. Center for European Studies, 4 (3), 316-322.

DPT. (2002). Sekizinci beş yıllık kalkınma planı yerel yönetimler özel ihtisas komisyonu raporu, DPT Yayınlar1.

Gibson, J., Miller, M., \& Wright, G. (1991). Location quotient: a basic tool for economic development analysis. Economic Development Review, 9(2), 65-68.

Glaeser, E.L., Kallal, H.D., Scheinkman, J.A., \& Shleifer, A. (1992). Growth in cities. Journal of Political Economy, 100(6), 1126-1152.

Henderson, J.V. (2003). Marshall's scale economies. Journal of Urban Economics, 53(1), 1-28.

Isserman, A.M. (1977). The location quotient approach to estimating regional economic impacts. Journal of the American Institute of Planners, 43(1), 33-41.

Karakayacı, Ö. (2010). Ekonomik büyüme ve girişimcilik aktivitelerinde kümeleşmenin rolü: Bursa ve Konya sanayi kümeleri örneğinde karşılaştırmalı bir araştırma. Megaron, 5(3), 149-159.

Leigh, L. (1970). The use of location quotients in urban economic base studies. Land Economics, 46(2), 202-205.

Meyer, J.R. (1963). Regional economics: A survey. American Economic Review, 53, 1-54.

Moineddin, R., Beyene, J., \& Boyle, E. (2003). On the location quotient confidence interval. Geographical Analysis, 35(3), 249-256.

Munandar, T.B., Azhari, Musdholifah A., \& Arsyad, L. (2017). Modified agglomerative clustering with location quotient for identification of regional potential sector. Journal of Theoretical and Applied Information Technology, 95(5), 1191-1199.

Nayyar, G. (2011). The quality of employment in India's services sector: exploring the heterogeneity. Applied Economics, 44(36), 4701-4719. https://doi.org/10.1080/00036846.2011.589816

Pan, F., Hall, S., \& Zhang, H. (2020). The spatial dynamics of financial activities in Beijing: agglomeration economies and urban planning. Urban Geography, 41(6), 849-864. https://doi.org/10.1080/02723638.2019.1700071

Parr, J.B. (2014). The regional economy, spatial structure and regional urban systems. Regional Studies, 48(12), 1926-1938. https://doi.org/10.1080/00343404.2013.799759

Porter, M. (1998). Clusters and new economics of competition. Harvard Business Review, 76(6), 77-90. 
Kayseri Üniversitesi Sosyal Bilimler Dergisí Cilt 3, Sayi: 1, Haziran 2021, 41-59

Kayseri University Journal of Social Sciences. Vol 3, NNo: 1, June 2021, 41-59

Porter, M.E. (2000). Location, competition, and economic development: Local clusters in a global economy. Economic Development Quarterly, 14(1), 15-34.

Potter, A., \& Watts, H.D. (2014). Revisiting Marshall's agglomeration economies: Technological relatedness and the evolution of the sheffield metals cluster. Regional Studies, 48(4), 603-623. https://doi.org/10.1080/00343404.2012.667560

Şahin, T.M, \& Türkoğlu, T. (2017). Türkiye' de mobilya imalat sanayinin mekânsal kümelenme örüntüsü: 2003-2014 y1lı karşılaştırmalı lokasyon katsayısı analizi. B. Ayhan, M. Ay, S. Avşaroğlu \& Ş. Akpınar (Ed.) içinde, Sosyal Bilimler ve Beşeri Bilimler Araştırmaları (ss. 428436), Çizgi Kitapevi.

Seçkin, E. (2015). Perakende sektöründeki yapısal dönüşümün Bursa'daki üretim piyasası ile tüketim piyasasına yansiması. Megaron, 10(1), 70-79.

Taştekin, A. (2018). Türkiye'de bölgesel kalkınma stratejileri ve bölge idareleri. Uluslararası Yönetim Akademisi Dergisi, 1(1), 69-83.

Tian, Z. (2013). Measuring agglomeration using the standardized location quotient with a Bootstrap Method. The Journal of Regional Analysis and Policy, 43(2), 186-197. 